\title{
Skills Acquisition in Plantain Flour Processing Enterprises: A Validation of Training Modules for Senior Secondary Schools
}

\author{
Nsikak-Abasi Udofia ${ }^{1, *}$, Bernard S. Nlebem ${ }^{2}$ \\ ${ }^{1}$ Department of Educational Foundations, Guidance and Counselling, University of Uyo, P.M.B. 1017, Uyo, Nigeria \\ ${ }^{2}$ College of Education, Afaha Nsit, Akwa Ibom State, Nigeria \\ *Corresponding Author: nsisong99@yahoo.com
}

Copyright (C) 2013 Horizon Research Publishing All rights reserved.

\begin{abstract}
This study was to validate training modules that can help provide requisite skills for Senior Secondary school students in plantain flour processing enterprises for self-employment and to enable them pass their examination. The study covered Rivers State. Purposive sampling technique was used to select a sample size of 205. Two sets of structured Questionnaires, divided into ten sections (A-J) were used for data collection. Data were analysed using mean for research questions and the hypotheses were tested using Analysis of variance (ANOVA) at 0.05 level of significance. The questionnaire was face-validated by five experts, and the reliability was tested using Cronbach's alpha reliability estimate to determine the internal consistency of the questionnaire this yielded a reliability coefficient $r$ of 0.977 . The findings revealed that the modules packaged for skills acquisition in plantain flour enterprise were all needed. The ANOVA results reveals no significant difference in the mean rating of the respondents (teachers of home economics, extensions agents and IITA staff) regarding the training modules packaged for student for skills acquisition in plantain flour processing was significant. The researchers recommended that the package should be used in the training of senior secondary student, inter alia.
\end{abstract}

Keywords Vocational Education, Skills Acquisition, Plantain flour Processing, Training Modules, Entrepreneurship Education

\section{Introduction}

The present Senior Secondary Education Curriculum (SSEC) is designed for human capital development that grows out of focused area of potential specialization. Graduates from the new SSEC are expected to possess relevant information and communication technology (ICT) skills and enterprise culture along with relevant technical, vocational and entrepreneurship skills and become well prepared for their world of work or for higher education as may be applicable. Candidates are to offer four compulsory cross-cutting subjects which include English language, General Mathematics, and one trade/ entrepreneurship subject to be selected from the list of 34 approved trade/entrepreneurship subjects and in addition subjects from four distinct fields of studies. It was in view of this that there was need to see how to develop the entrepreneurship based on the nature of the environment. Rivers State in Nigeria is blessed with plantain in addition to other natural resources. This is in line with the demand of the new curriculum [1].

Plantains are classified formally as Musa balbisiana or hybrids Musa acuminate $\mathrm{x}$ balbisiana, depending on their genetic constitution. Fellow [2] stated that plantain is the common name for herbaceous plants for the genus Musa. The fruit they produce is generally used for cooking in contrast to the soft, sweet banana (which is sometimes referred to as desert banana). Fellow [2] also confirmed that there is no formal botanical distinction between banana and plantains, the use of either term is based purely on how the fruits are consumed. However, he affirmed that plantains tend to be firmer and lower in sugar content than desert banana. Bananas are most often eaten raw while plantains are mostly cooked or otherwise processed.

International Institute for Tropical Agriculture (IITA) [3] affirmed that plantain is a giant herb with an underground rhizome (commonly called a corm), surmounted by a growing point. Lateral buds produce suckers, which together with the parent corn make up the Stoll or mats. They further identified about 116 different cultivars in Nigeria, which they said, can be classified into three groups namely:

1. Unereike (French plantain)

2. Bini plantain (Okirika in parts of Rivers State)

3. Horn plantain (Ogbutun)

These three groups are in abundance in Rivers State.

Plantain is one of the major staple food crops, third after cassava and yam grown by farmers in Rivers state [4]. 
People in Rivers State use plantain as trade commodity for income generation, industrial raw materials and farming.

Haba [5] remarked that plantain fruits deteriorate rapidly and therefore must be processed into several products of industrial market value with a view to diversifying their products base. The products according to IITA [3], include, flour, bread, biscuit, chips, cake and chin-chin. The report further stated that the products are important raw materials for livestock feed, confectionary, bakery and pharmaceutical industry. The report also confirmed that other benefits derivable from processing plantain include increase in shelf life of the products. Still on plantain processing, Fellow [2], stated that locally produced foods, such as plantain are plentiful at certain times and scare at others, therefore processing plantain brings the benefits of availability at the scarce time a more varied and interesting diet.

On the supply of processed plantain, Fellow [2] stated that the supply of processed plantain can be the basis of a profitable small scale business, which is lacking in Rivers State but is highly needed for employment of the teeming population of out-of-school youths. The author indicated that many traditional foods are made from memory of small-scale producer's techniques that were handed down from generation to generation by words of mouth without documentation. There could be a reversal of this situation for the out-of-school youths, if exposed to training programmes for the acquisition of the relevant skills in plantain products processing [6-9].

The researcher had observed that the inability of students to establish small-scale enterprises of their own hinged on certain conditions that prevent them from succeeding. These include the non-facilities for training. Most of the out-of-school youths cannot help themselves financially. Although this study focuses on training modules for skills in plantain products processing in Rivers State, the findings would serve as source of inputs for planning and implementing programme on training modules for schools students' acquisition of skills in plantain products processing in other states of the Federal Republic of Nigeria, including Akwa Ibom State.

\section{Research Question}

The following research questions guided this study

1. What is the mean score of each item of the training modules for students in Rivers State for skills in plantain flour enterprises?

2. What training modules are essential for students in Rivers State for skills in plantain flour enterprises?

3. What training modules are practicable for Rivers State youths for skills acquisition in plantain flour into bread processing enterprise?

\section{Hypothesis}

The following hypothesis were tested at $\mathrm{p}<0.05$ level of significance.

1. The mean scores of each item of the training modules by the Stakeholders in plantain flour processing for students in Rivers State for skills in plantain flour enterprises is not significant.
2. There is no significant difference in the responses among home economics teachers, Extension Agents (EAs) and IITA staff, on the training modules that can be packaged for students for skills acquisition in plantain flour producing enterprise.

\section{Methodology}

The study made use of two research designs which are Research and Development (R and D) designs. The study was carried out in Rivers State. The population of this study was 598 comprising 20 (IITA) staff 71 Agricultural Extension Agents (EAs) and (498) Home Economics Teachers.

The sample size for this study was 269 respondents made up of 20 (IITA) staff, 27 Agricultural Extension Agents (EAs) mostly Women in agriculture (WAI) and 222 Home Economics Teachers. The (IITA) staff and Women in Agriculture (WIA) populations were small and therefore were purposively chosen. The population size of teachers was large and therefore, Yare Yemeni's formula was employed which yielded 222 teachers. The questionnaire items had 4-points rating scale (options) of "Highly needed" (4) "Averagely needed" (3), "Slightly needed" (2) and "Not Needed" (1).

The two sets of structured questionnaire were face validated by experts. Cronbach's Alpha reliability method was utilized to determine the internal consistency of the two sets of questionnaire.

Five research assistants with the researcher helped to administer 269 copies of the questionnaire to the respondents, in their various locations. A total of 205 copies (78.84) return rate of the questionnaire were retrieved from the respondents for analysis. The data collections were analyzed using weighted mean and standard deviation to answer the research questions: while ANOVA was used to test the hypotheses at 0.05 levels of significance.

\section{Results}

Data presented in Table 1 showed that the six planning skills (module A) in plantain flour processing had mean values above the mean between 3.50-4.00, similarly, the ten management skills (module B); for organizing skills (module C); six marketing skills (module D); seven material resources skills (module E); four waste and by-product management skills (module F); five maintenance of facilities and safety practices skills (module G); six instructional training procedures skills (module $\mathrm{H}$ ); five instructional planning (component) (module I) and nine instructional training procedure implementation (modules $\mathrm{J}$ ), all had mean values above between 3.50-4.00.

Deduction from the analysis showed that all the skills in modules A-J are all highly essential and practicable for the training of students in plantain flour processing enterprise. 
Table 1. Training Modules in plantain Flour Product Processing Enterprise

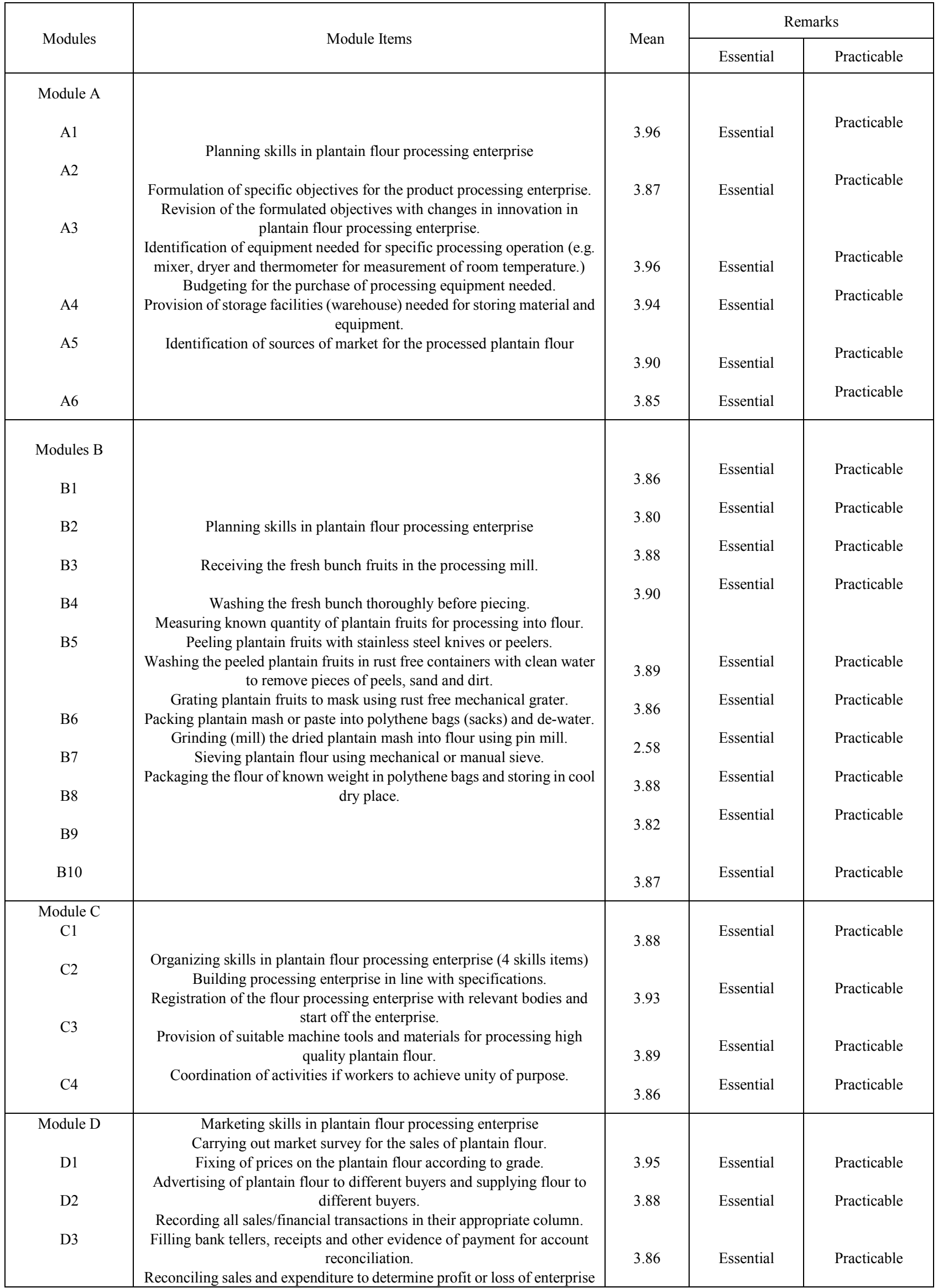




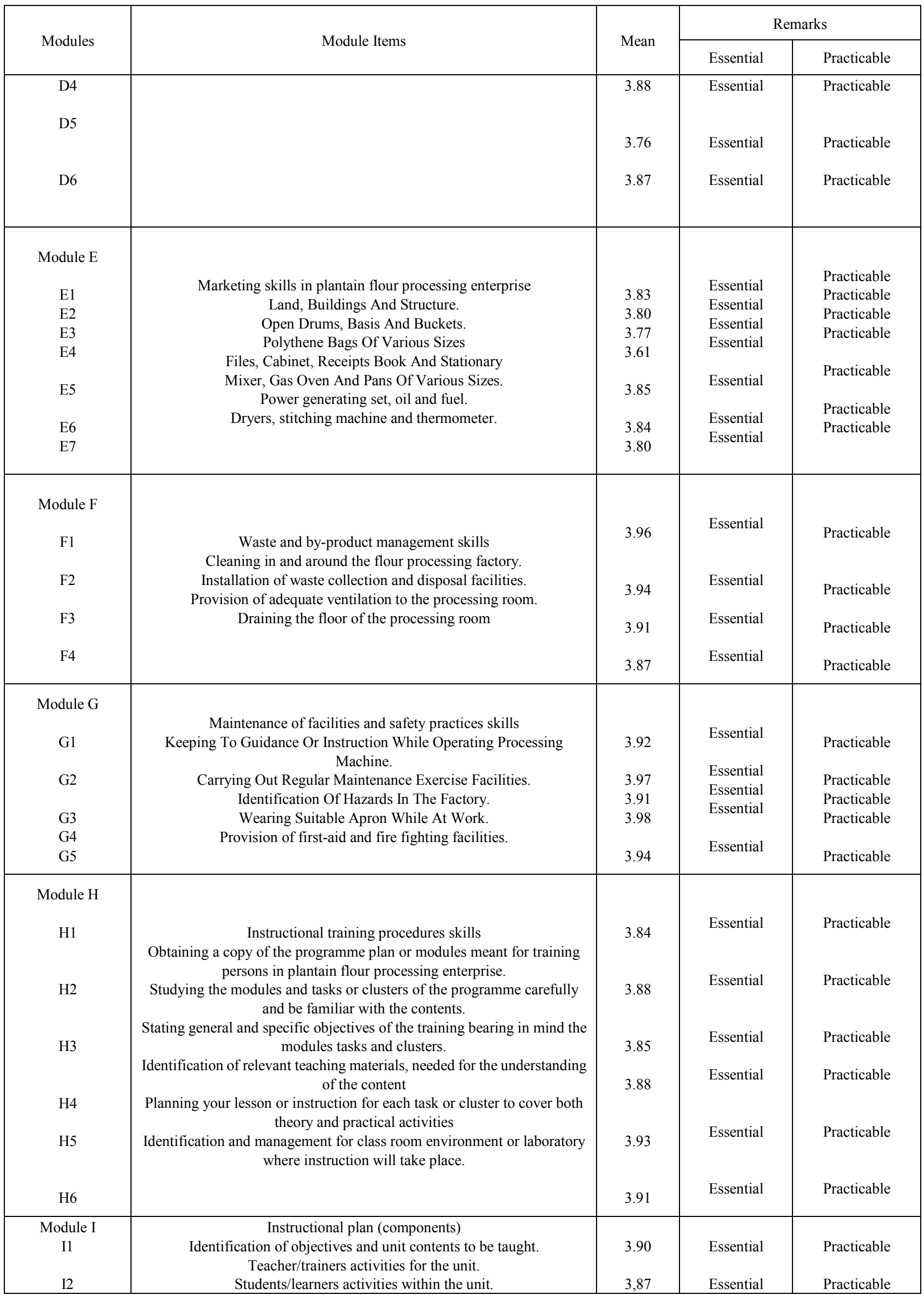




\begin{tabular}{|c|c|c|c|c|}
\hline \multirow{2}{*}{ Modules } & \multirow{2}{*}{ Module Items } & \multirow{2}{*}{ Mean } & \multicolumn{2}{|c|}{ Remarks } \\
\hline & & & Essential & Practicable \\
\hline $\begin{array}{l}\text { I3 } \\
\text { I4 } \\
\text { I5 }\end{array}$ & $\begin{array}{l}\text { Instructional material for the unit. } \\
\text { Method of evaluating the unit }\end{array}$ & $\begin{array}{l}3.83 \\
3.85 \\
3.63\end{array}$ & $\begin{array}{l}\text { Essential } \\
\text { Essential } \\
\text { Essential }\end{array}$ & $\begin{array}{l}\text { Practicable } \\
\text { Practicable } \\
\text { Practicable }\end{array}$ \\
\hline \multicolumn{5}{|l|}{ Module J } \\
\hline $\mathrm{J} 1$ & & 3.91 & Essential & Practicable \\
\hline $\mathrm{J} 2$ & $\begin{array}{l}\text { Instructional training procedure implementation } \\
\text { Teaching trainees from known to unknown concepts using module A-J }\end{array}$ & 3.90 & Essential & Practicable \\
\hline $\mathrm{J} 3$ & $\begin{array}{l}\text { Explanation of different terms in plantain flour enterprise. } \\
\text { Explanation to the trainees such facilities and equipment needed for } \\
\text { specific operations and how they can be used. }\end{array}$ & 3.96 & Essential & Practicable \\
\hline $\begin{array}{l}\mathrm{J} 4 \\
\mathrm{~J} 5\end{array}$ & $\begin{array}{l}\text { Demonstration of the skills step-while the trainees observe. } \\
\text { Causing the trainees to learn by doing what the instructor demonstrated } \\
\text { while the instructor observes. }\end{array}$ & 3.95 & Essential & Practicable \\
\hline J6 & $\begin{array}{l}\text { Correction of any mistake made by trainees during practice of any skill. } \\
\text { Encouraging visits to other flour processing enterprise and writing of }\end{array}$ & 3.95 & Essential & Practicable \\
\hline $\mathrm{J} 7$ & $\begin{array}{l}\text { Discussion of common hazards trainees are likely to experience in their } \\
\text { environment. }\end{array}$ & 3.81 & Essential & Practicable \\
\hline J8 & & 3.88 & Essential & Practicable \\
\hline J9 & & 3.85 & Essential & Practicable \\
\hline
\end{tabular}

Table 2. ANOVA on Training Modules in Plantain Bread Processing Enterprise

\begin{tabular}{|c|c|c|c|c|c|c|c|}
\hline Module & Module Items & Group & Sum of square & $\mathrm{df}$ & $\mathrm{F}$ & Sig. & $\mathrm{Rk}$ \\
\hline A & $\begin{array}{c}\text { Planning skills in plantain flour processing } \\
\text { enterprise }\end{array}$ & $\begin{array}{l}\text { Between } \\
\text { Within } \\
\text { Total }\end{array}$ & $\begin{array}{c}2.70 \\
264.46 \\
267.15\end{array}$ & $\begin{array}{c}2 \\
202 \\
204\end{array}$ & 1.030 & .395 & NS \\
\hline B & $\begin{array}{l}\text { Management skills in plantain flour processing } \\
\text { enterprise }\end{array}$ & $\begin{array}{l}\text { Between } \\
\text { Within } \\
\text { Total }\end{array}$ & $\begin{array}{c}199.02 \\
5765.69 \\
5884.70\end{array}$ & $\begin{array}{c}2 \\
202 \\
204\end{array}$ & 2.086 & .127 & NS \\
\hline $\mathrm{C}$ & $\begin{array}{c}\text { Organizing skills in plantain flour processing } \\
\text { enterprise }\end{array}$ & $\begin{array}{l}\text { Between } \\
\text { Within } \\
\text { Total }\end{array}$ & $\begin{array}{c}4.05 \\
328.44 \\
332.49\end{array}$ & $\begin{array}{c}2 \\
202 \\
204\end{array}$ & 1.25 & 2.90 & NS \\
\hline $\mathrm{D}$ & $\begin{array}{l}\text { Marketing skills in plantain flour processing } \\
\text { enterprise }\end{array}$ & $\begin{array}{c}\text { Between } \\
\text { Within } \\
\text { Total }\end{array}$ & $\begin{array}{c}14.65 \\
936.47 \\
951.12 \\
\end{array}$ & $\begin{array}{c}2 \\
202 \\
204 \\
\end{array}$ & 1.58 & .208 & NS \\
\hline $\mathrm{E}$ & $\begin{array}{l}\text { Materials resources needed in plantain flour } \\
\text { processing enterprise }\end{array}$ & $\begin{array}{l}\text { Between } \\
\text { Within } \\
\text { Total }\end{array}$ & $\begin{array}{c}7.54 \\
649.71 \\
951.12\end{array}$ & $\begin{array}{c}2 \\
202 \\
204\end{array}$ & 1.17 & .312 & NS \\
\hline $\mathrm{F}$ & Waste and by-product management skills & $\begin{array}{l}\text { Between } \\
\text { Within } \\
\text { Total }\end{array}$ & $\begin{array}{c}2.44 \\
226.67 \\
229.10\end{array}$ & $\begin{array}{c}2 \\
202 \\
204\end{array}$ & 1.0 & .340 & NS \\
\hline G & $\begin{array}{l}\text { Maintenance of facilities and safety practices } \\
\text { skills }\end{array}$ & $\begin{array}{c}\text { Between } \\
\text { Within } \\
\text { Total }\end{array}$ & $\begin{array}{c}.53 \\
107.06 \\
107.06 \\
\end{array}$ & $\begin{array}{c}2 \\
202 \\
204\end{array}$ & .502 & .606 & NS \\
\hline $\mathrm{H}$ & Instructional plan (components) & $\begin{array}{l}\text { Between } \\
\text { Within } \\
\text { Total }\end{array}$ & $\begin{array}{c}10.50 \\
768.75 \\
779.25\end{array}$ & $\begin{array}{c}2 \\
202 \\
204\end{array}$ & 1.380 & .254 & NS \\
\hline I & Instructional plan (components) & $\begin{array}{l}\text { Between } \\
\text { Within } \\
\text { Total }\end{array}$ & $\begin{array}{c}2.28 \\
3.36 .01 \\
339.59\end{array}$ & $\begin{array}{c}2 \\
202 \\
204\end{array}$ & 1.076 & .343 & NS \\
\hline $\mathrm{J}$ & $\begin{array}{l}\text { Instructional training procedures } \\
\text { implementation }\end{array}$ & $\begin{array}{l}\text { Between } \\
\text { Within } \\
\text { Total }\end{array}$ & $\begin{array}{c}5.60 \\
608.01 \\
613.61\end{array}$ & $\begin{array}{c}2 \\
202 \\
204\end{array}$ & .931 & .396 & NS \\
\hline
\end{tabular}

Significant at .05 alpha level: critical F-value $=3.040 \mathrm{do}=2$ and 202 
The Analysis of Variance presented in Table 2 reveals that the calculated F-value of 1.030 modules A; planning skills, 2.086 management skills module $\mathrm{B}$; 1.25 modules $\mathrm{C}$; organizing skills 1.58 module D; marketing skills, 1.17 module $\mathrm{E}$; material resources 1.09 module $\mathrm{F}$; waste and by-product management skills; 502 module G; maintenance of facilities procedures skills, 1.076 module I; instructional components skills and .931 module $\mathrm{H}$; instructional training procedures skills, 1.076 module I; instructional components skills and .931 module $\mathrm{J}$; instructional training procedures implementation skills are all less than the critical F-value (F-tabulated) of 3.040 at .05 alpha level with 2 and 202 degree of freedom. The hull hypothesis (HO2) of no significant difference in the responses of the respondents, on the training modules packaged for skills acquisition on plantain flour processing enterprise was therefore upheld.

Deduction from the hypothesis tested indicated that the 10 modules are needed for training of out-of-school youths for skills acquisition in plantain bread processing enterprise.

There was no significant difference in the mean rating of the responses of home economics teachers, extension agents, and IITA staff on the training modules packaged for skills acquisition in plantain bread processing enterprise.

\section{Discussion}

Necessary facilities and material resources needed for successful plantain product processing enterprise were outlined or listed. These facilities appear to be indispensable to modern or mechanized plantain products processing enterprise for effective management and profit maximization.

The training modules for skills-acquisition for out-of-school youths have implication for Rivers State skills Acquisition Centres (RSSAC). As the supervisory body of youths in skills acquisition; it will help them organized wide range of programmes periodically on plantain products processing enterprise, for out-of-school youths aimed at reducing out-of-school youths unemployment rate. If this is done, it will make out-of-school youths to be aware of training programmes in plantain products processing enterprise. They will also be aware of the enterprise to engage on, as well as overcoming the phobia associated with starting the enterprise, and seeking necessary advice from (RSSAC). It will help the organizers of youth bodies on some educational programmes or enlightenment towards making out-of-school youths favourably disposed to benefiting from any of the plantain products processing enterprise.

If the training modules packaged for out-of-school youths, for skills acquisition in plantain products processing are adopted and implemented, by the various group concerned with out-of-school youths skills acquisition and self-employment, then more opportunities of self-employment for out-of-school youths will be possible.

The study has implication for out-of-school youths,
Extension Agents (EAs) of Rivers State Agricultural Development programme (RSADP), government agency that train youths for skills acquisition, as well as Corporate Organization concerned with out-of-school youths skills acquisition.

Organizations that are concerned with out-of-school youths aware and exposed to plantain products processing for self-employment. It will go a long way to broaden their knowledge on plantain products processing an which of the plantain product enterprise to advice out-of-school youths to embark on, when seeking for out-of-school youths skills acquisition training, in the same vein the study has implication for Extension Agents (EAs) for Rivers State Agricultural Development Programme (RSADP) in choosing the enterprise that is cheaper and with higher profit for training out-of-school youths. The result is bound to encourage more out-of-school youths participation in plantain products processing enterprise.

\section{Conclusion and Recommendations}

From the findings of this study, training modules for school students for skills acquisition in plantain flour processing enterprises should be used to train and instruct students according to the demand of the new curriculum.

Based on these findings, the following are recommended:

1. The government of Rivers State should direct the management of Skill Acquisition Centres (SACs) to integrate the identified and packaged training modules into their skills acquisition programmes, this will facilitate the training of students and others interested youths in plantain products processing enterprise.

2. The government should make the findings of this study available to the media for dissemination to the general public including out-of-school youths.

3. The out-of-school youths and other interest youths could make choice of any of the enterprise and register for training in any skill acquisition centre in the state.

4. The Niger Delta Development Commission (NDDC) should make use of the identified plantain products processing enterprises in training their youths in the entire states that produces oil in the country.

5. The entrepreneurs in the plantain processing industry in the state should be allowed access to the skill items in the training modules, as identified in this study as $\mathrm{t}$ enable them improve on their production.

6. Educators in entrepreneurship should strive to follow the pattern of this study and develop standardized modules for school based entrepreneurship education in various skills to ease teaching, learning and research in the field of entrepreneurship education.

7. International funding organisations should initiate 
and sponsor the development of training modules in entrepreneurship education, especially in third world countries like Nigeria.

\section{REFERENCES}

[1] NERDC (2008). Federal ministry of education ; Senior Secondary School Education curriculum. Abuja ,NERDC

[2] Fellow, (2007). Bananas and plantain. Review of Bananas and plantain (IITA) production .Retrieved from http //www. Botgard. Ucla.edu/html/botany textbooks economy botany /musa/index.html on 27/09/2009

[3] IITA (2005). Plantain in Tropical Africa: A Referenced Manual. Ibadan: IITA
[4] Simonds, N. M. (2008) Banana. London : beam and co

[5] Haba, S.K. (2004). Traditional processing and utilization of cassava in Africa. Retrieved from file;//A;/)4/special.htm on 9/12/2006

[6] Christensen, A. P. (2001). Small and Medium Scale Business Enterprise. London McGraw Hill International.

[7] CAIS (2007). Record Keeping in the Service Industry by Commonwealth of Australia. Retrieved from Fill;/record keeping in the industry/htm on 16/09/2008.

[8] Boutccher, B. A. (2002). Plantain and Banana Production. Retrieved from http/en.wlk/pedia.org./wiki/process on 16/10/2009.

[9] Bello, T. (2003). Attacking Unemployment Hurdles in the Fragile Economics of the Sub-Saharan Africa: The Experience of Nigeria. A paper Presented at the Economics for Future Conference, Cambridge, United Kingdom. 